\title{
USING 3D MODELING TO PROMOTE RAILWAY HERITAGE. THE RAILWAY STATION OF CURTEA DE ARGEŞ MUNICIPALITY AS CASE STUDY
}

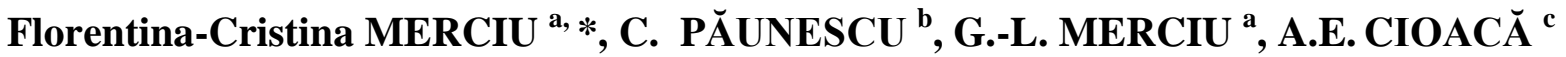 \\ ${ }^{a}$ University of Bucharest, Faculty of Geography, Human and Economic Geography Department, Interdisciplinary Center of \\ Advanced Research on Territorial Dynamics, 1 Blvd. Nicolae Bălcescu, Bucharest, Romania, E-mails: \\ *cristina.merciu@geo.unibuc.ro, george.merciu@geo.unibuc.ro \\ ${ }^{\mathrm{b}}$ University of Bucharest, Faculty of Geology and Geophysics, Geomatica Research Center, 6 Traian Vuia, 020956, Bucharest, \\ Romania, E-mail: cornelpăun@gmail.com \\ ${ }^{\mathrm{c}}$ Cornel\&Cornel Topoexim, 31, Vidra, Bucharest, Romania, E-mail: cioaca.alexandru@ topoexim.ro
}

Received: 30.08.2021 / Accepted: 10.09.2021 / Revised: 25.10.2021 / Available online: 15.12.2021

DOI: 10.2478/jaes-2021-0016

KEY WORDS: industrial heritage, architectural value, volumes, terrestrial photogrammetry, aerial photogrammetry, 3D model

\begin{abstract}
:
The characteristics of the industrial heritage (antiquity, architectural, cultural, technological value) determined its inscription in the category of historical monuments. In recent years, non-invasive digital technologies have been used in studies focused on documenting, digitizing, preserving elements of industrial heritage. Also, another objective of digitizing the industrial heritage is to facilitate its promotion as a cultural resource among the general public. The purpose of this study is to promote the railway station of Curtea de Argeş through non-invasive technology. The analyzed industrial monument represents a symbolic building of the neoRomanian architectural style. The building is also associated with a remarkable historical value: the railway station was also used by the Romanian royal family. Based on the use of terrestrial photogrammetry (versatile GNSS RTK GS18 I sensor) and aerial (photogrammetric flight), the authors created the 3D model of the station, obtaining a high-resolution modeling. The results of this study reflect the usefulness of modern technology for documenting, 3D modeling and promoting an industrial monument inscribed on the list of national cultural heritage. The accuracy and optimal performance of the measurements made, using GNSS technology and aerial photogrammetry, allowed highlighting the remarkable architectural and volumetric characteristics of the railway station of Curtea de Argeş Municipality.
\end{abstract}

\section{INTRODUCTION}

The inclusion of the railway transport elements in the sphere of cultural heritage was made relatively late (in the second half of the 19th century), as a result of belonging to the industrial field (Hecker, 2008). The main obstacle of classifying the elements of railway heritage as cultural goods was represented by the lack of recognition of its cultural and technological values, which results from its perception as an element of infrastructure with ordinary qualities (Hecker, 2008).

Against the background of deindustrialization, many elements of railway transport have been decommissioned, an issue that has come to the attention of the international community since the 70 s of last century (Bazac, 2021). In this context, in order to maintain the functionality of the old railways and to preserve the engineering structures, urban regeneration projects with economic, environmental, social and cultural implications were started.
For the implementation of industrial sites regeneration projects, high-level cooperation between various stakeholders is needed, which takes the form of collaborative management (Popoviciu, 2012). Railway elements have been reused for cultural purposes (museums, exhibition spaces) (Bazac, 2021; Cano Sanchiz et al., 2020; Dorobanţu, 2020; Ekimci et al., 2019; Merciu et al., 2014; Michniack, 2016), tourism (tourist railways, hotels, restaurants) (Bazac, 2021; Michniack, 2016; di Ruocco et al. 2017), as office spaces for activities in the field of creative industries (Ekimci et al., 2019), etc.

The large size of industrial buildings and heritage sites, as well as their strategic location (usually in the central or pericentral area of cities), also generates an approach from the perspective of economic profitability of urban regeneration projects. (Merciu et al., 2014; Merciu, 2020). Preservation of cultural heritage is often seen as a factor limiting the development of the cities (Merciu, 2020; Messaoudi et al., 2021; Nae et al., 2019; Taloş et al., 2021).

\footnotetext{
* Florentina-Cristina Merciu, Teaching Assistant, University of Bucharest, Faculty of Geography, Interdisciplinary Center of Advanced Research on Territorial Dynamics, E-mail: cristina.merciu@geo.unibuc.ro, Romania.
} 
Adaptive reuse is also an action to highlight the elements of industrial heritage (Merciu et al., 2014) that allows the general public to be aware of the historical and cultural significance of industrial monuments.

In recent years, modern technology has been used more and more frequently as a tool for documentation, accurate monitoring, digitization, conservation and promotion of cultural sites among the general public (Jo and Hong, 2019; Herman et al., 2020; Martín-Lerones et al., 2021; Nistor et al., 2011; Rădulescu et al., 2021; Tache et al., 2019).

2D and 3D virtual representations are also useful for interactive presentation and promotion of industrial heritage elements: 3D models made with laser scan (Corso et al., 2013; Herner, 2019; Monego et al., 2017), the Building Information Modelling (BIM) technology (Carnevali et al., 2019; Wu et al., 2015) or Global Navigation Satellite System (GNSS) (Monego et al., 2017), aerial photogrammetry based on state-of-the-art technology (drones, LiDar) (Piras et al., 2017; Opitz et al., 2015), GIS storytelling (López and Cruz, 2021; Merciu, 2015).

This paper aims to promote the railway station of Curtea de Argeș Municipality, an industrial monument of national importance, using non-invasive technology (versatile GNSS RTK GS18 I sensor and photogrammetric flight).

\section{DESCRIPTION OF THE CASE STUDY}

The need for this study results from the cultural importance of the railway station of Curtea de Arges municipality, which is a symbolic building of the neo-Romanian architecture, to which is added the historical value: the railway station was used by the Romanian royal family (Curtea de Argeș was the royal residence, with important Voivodeship and royal necropolises) (Brie, 2005). The railway station was built between 1896 -1898, under the coordination of the engineer Elie Radu (Mănescu et al., 2003).

The railway station is individualized by architecture of a "domestic" monumentality, which combines in a balanced way elements and proportions specific to Romanian architecture. (windows in full arch, marked by the polychrome glazed ceramic frames of level 1 of the side bodies, twisted girdles present on the entire contour of the building, visually separating the two levels) with neo-Gothic decorative elements concentrated on the pediment of the central body, marking the cornice and the twin windows of level 1 of the pediment (Mănescu et al., 2003, pp. 106-107). The promotion of the national style was established as a priority at the end of the 19th century, in literature and arts, a movement supported by King Carol I (Mănescu et al., 2003, p. 107). The two towers mark the centrality by symmetry (Figure 1 . a and $b$ ).
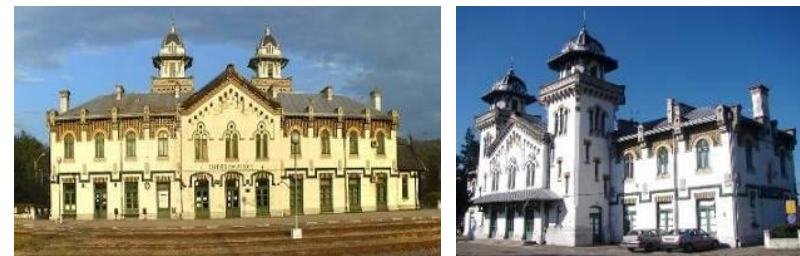

Figure 1. Picture of railway station (a main façade, b. Northeast view)
Due to its architectural, historical, cultural and aesthetic plurivalences, the railway station of Curtea de Argeş Municipality is classified as a historical monument of national importance (code AG-II-m-A-13627) (List of Historical Monuments, 2015). The building occupies an area of 507 square meters.

\section{METHODOLOGY}

In this paper are used some of the main geomatic methodologies for obtaining the 3D model, from classic topography and the versatile GNSS RTK Leica GS18I sensor, to aerial photogrammetric flight.

Leica GS18I is an RTK GNSS rover, a dual frequency receiver, which allows the measurement of topographic points, with the help of images. To measure points, the sensor uses innovative virtual positioning technology based on the integration with the Global Navigation Satellite System (GNSS) and Inertial Measurement Unit (IMU) of a video camera (Leica ARO 135). When the chosen point is identified in consecutive images, the 3D position of the point is constructed using the forward intersection. In order for the measurement in the images to have an optimal accuracy and performance, the railway station was captured from a distance of $8 \mathrm{~m}$.

The rover uses real-time positioning (RTK) services that involve the transmission of information called differential corrections via the Internet. These services are provided by the Romanian Positioning System (ROMPOS). In order to measure points, the GS18I sensor must receive signals from the satellite. Using satellite data, the $3 \mathrm{D}$ coordinates of the ground point are measured with an accuracy of less than 1 centimeter (Monego et al., 2017).

The processing of the captured data was performed by the authors in the Leica Infinity program (Figure 2).

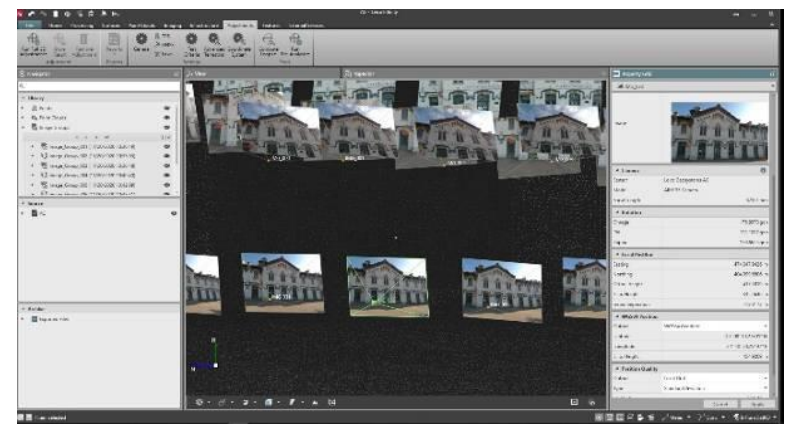

Figure 2. Graphic view of the data processing measured in the Leica Infinity program

The data processing also resulted in the creation of point clouds resulting from the measurements with versatile GNSS RTK Leica GS18I sensor, which were processed, aligned and georeferenced in the reference system of the topographic network (Figure 3). 


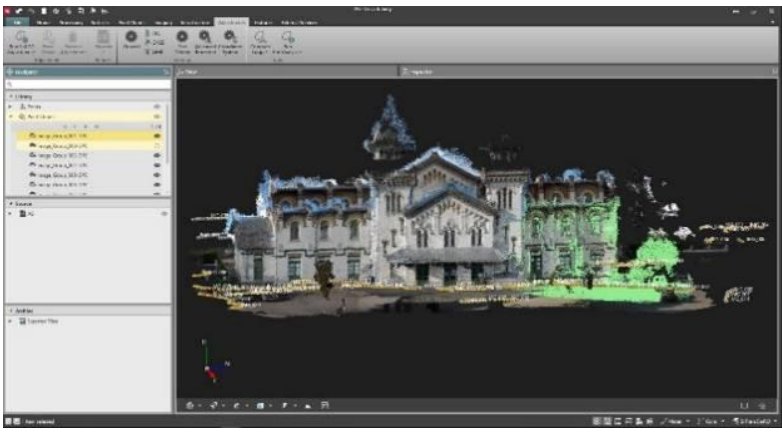

Figure 3. Creating point clouds from date captured on the ground and building the $3 \mathrm{D}$ model

It was also necessary to use photogrammetric flight to scan the roof of the building. For data processing, the UltraCam Eagle M3 photogrammetric system used on a Beechcraft 200 Super King Air was used on an aerial platform. The software suite allows workflows for digital photogrammetry production, including automatic creation, orientation and triangulation of aerial images. Following the calculation of the exterior orientation, a dense point cloud was created for the roof of the building.

\section{RESULTS AND DISCUSSIONS}

In order to create the 3D model of the railway station of Curtea de Argeş Municipality, the points of interest were measured with the Leica GS18 I sensor during a field campaign in March 2021. The sensor was used with a measuring staff, held upright or tilted, due to the integrated IMU sensor, to measure the building footprint. Thus, 5,913,872 points were collected. Positioning the camera towards the building, the field operators walked along the main and side facades, while the camera automatically captured 989 images. The building was captured up to a height of $12 \mathrm{~m}$.

The images were processed automatically by the application associated with the sensor. The Leica Infinity application automatically processes, positions and orients the captured images, thus ensuring the preservation of the quality of the measurements performed in the field.

The end result was a point cloud that defines the entire building (Figure 4). By capturing images on the same object, point cloud alignment takes place. The 3D model was processed to obtain a complete set of data that were classified into several categories, according to: point intensity (Figure 4 . a and b), point density (Figure 4. c and d), by elevation (Figure 4. e and f), RGB model (Figure 4. g and $\mathrm{h}$ ). The point cloud resulting from measurements performed with the versatile GS18I sensor is of high density (Figure 4. a and b).

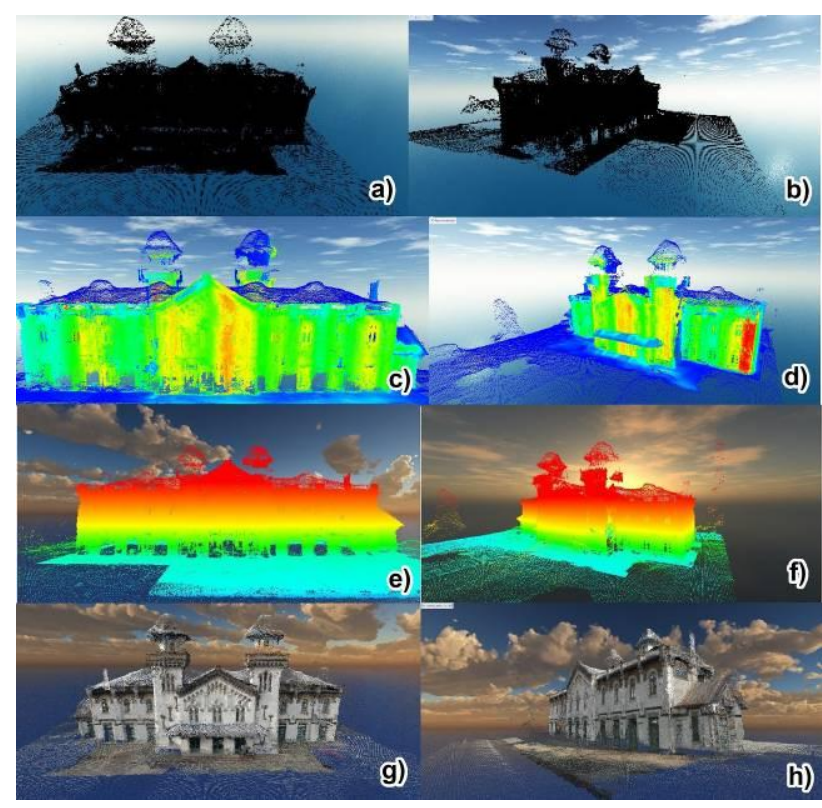

Figure 4. Results obtained from data processing (a, b. Intensity of points; c, d. Dense cloud of points; e, f. Elevation - symbology according to the height from the ground; g, h. RGB 3D model visualization of tiny details rendered in color on the structure of 3D objects; the information is stored in a digital format and kept in separate color bands (red, green and blue)

The accuracy and optimal performance of the measurements made with the versatile GNSS RTK Leica GS18I sensor allow highlighting the remarkable architectural and volumetric characteristics of the building (Figure 4. $g$ and $h$ ).

Similar results were obtained in other studies based on the use of the same technology (GNSS) (Monego et al., 2017) or laser scan (Corso et al., 2013; Herner, 2019).

Research in the field of cultural heritage is proving to be more and more complex, increasingly using knowledge from other fields, which reflects its interdisciplinary nature. Modern technology, which proves a very fast and wide development, is extremely useful in the field of cultural heritage research because it offers a permanent technological support in the activities of documentation, conservation, 3D reconstruction, promotion (Betti et al., 2021; Carnevali et al., 2019; Herman et al., 2020; Martín-Lerones et al., 2021; Nistor et al., 2011; Rădulescu et al., 2021; Sun et al., 2020; Xiao et al., 2018; Xu et al., 2021).

The particular characteristics of buildings and industrial heritage sites, such as their age and very large size, impose a number of difficulties in the process of their conservation (Nistor and Buda, 2013; Opitz et al., 2015; Wu et al., 2015). Modern technology offers multiple solutions to meet the challenges of conserving industrial heritage. Thus, in recent years there has been an increase in the number of studies focused on the use of modern technology, both for the conservation and promotion of industrial heritage (Corso et al., 2013; Herner, 2019; Merciu, 2015; Monego et al., 2017; Piras et al., 2017). The results obtained based on the use of non-invasive technologies (3D models, storytelling) can be easily used by third parties to promote the industrial heritage on computers or on the Internet (Corso et al., 2013; Herner, 2019). Digitization is a tool increasingly used by 
technical museums to protect and promote elements of industrial heritage (buildings, collections) (Herner, 2019).

The digitization of the industrial heritage is also used for educational purposes, due to the fact that it can contribute to the assimilation of its characteristics, as well as to its fixation in the consciousness of the general public as a cultural resource.

\section{CONCLUSIONS}

Non-invasive technology contributes to the promotion of industrial heritage elements, as well as to the understanding of their importance and significance.

Realization and analysis of 3D models, of industrial sites or of the collections of industrial objects within the technical museums, are used for documentation, monitoring, conservation and promotion of industrial heritage elements. These results can be obtained using multiple modern non-invasive technologies: terrestrial photogrammetry, aerial photogrammetry, laser scan or a combination thereof. The selection of a certain method or the combination of several methods depends on several factors such as: complexity and size of industrial sites, ensuring high resolution accuracy, location constraints, technical characteristics of the tools, purpose of using the method (promotion among specialists or among general users), etc.

Along with 3D laser scanning, terrestrial photogrammetry is increasingly applied in the field of cultural heritage, including for the digitization of industrial buildings classified as historical monuments. In recent years there has been a very rapid development of computer technology and specialized software necessary for processing the obtained data. For example, the versatile GS18 I sensor is part of the new technology, which allows measuring points in a shorter time.

The current difficult situation generated by the COVID-19 Pandemic has considerably limited the conservation of industrial heritage elements, the most affected being the small technical museums that are based on visitors' incomes and members' volunteer actions.

It can also be appreciated that $3 \mathrm{D}$ modeling is very useful for the promotion and conservation of industrial heritage which is less known as a cultural resource among the general public compared to other cultural assets (architectural heritage, churches, museums).

This study focuses on creating a 3D model of an industrial monument with multiple valences (architectural, historical and cultural) using the versatile GNSS RTK GS18I sensor and photogrammetric flight. This study highlights the usefulness of 3D modeling in promoting the railway station of Curtea de Argeş Municipality, classified as a historical monument of national importance.

\section{ACKNOWLEDGEMENTS}

This work was supported by the research project: "Complex multidisciplinary platform for integrative and systemic research of identities and tangible and non-tangible cultural heritage in Romania" - UEFISCDI project no. PN-III-P1-1.2-PCCDI-20170686.

\section{References}

Bazac, T., 2021. Modele de urmat pentru reconversia sustenabilă a patrimoniului industrial feroviar românesc (Models to follow for the sustainable reconversion of the Romanian railway industrial heritage). Annals of the Professional Association of Romanian Geographers, 12(12), in process of publication.

Betti, M., Bonora, V., Galano, L., Pellis, E., Tucci, G. and Vignoli, A., 2021. An integrated geometric and material survey for the conservation of heritage masonry structures. Heritage, 4(2), pp. 585-611.https://doi.org/10.3390/heritage4020035

Brie, M. 2005. A social history of Romanian space. From the begining of Dacian state until the rise of modernity. MPRA paper no. 44567.https://mpra.ub.uni-muenchen.de/44567/ (view 20 Aug. 2021).

Cano Sanchiz, J.M., Zhang, R. and Lei, L., 2020. The image of railways in China: museums, technology and narratives of progress. Hist. Environ.: Policy Pract., 11(2-3), 258-281. https://doi.org/10.1080/17567505.2020.1737312

Carnevali, L., Lanfranchi, F. and Russo, M., 2019. Built information modelling for the 3D reconstruction of modern railway stations. Heritage, 2, pp. 2298-2310. https://doi.org/10.3390/heritage2030141

Corso, J.M., Marambio, A. and Garcia-Almirall, P., 2013. Industrial heritage, the Fabra i Coats engine room in Barcelona: a terestrial laser scanning pointcloud classification. In: Forum Internazionale di Studi, Le Vie dei Mercanti, Heritage, Architecture Landesign. Capri, Italy, Vol. XI, pp. 150-159.

Dorobanţu, M., 2020. Linia ferată Bucureşti-Giurgiu în ultimii 51 de ani: de la aniversarea centenarului la provocările perioadei actuale (Bucharest-Giurgiu railway in the last 51 years: from the centennial anniversary of the line to the challenges of the current period). Annals of the Professional Association of Romanian Geographers, 11(11), pp. 5-16. http://www.apgr-anale.com/448500377

Ekimci, B., Ergincan, F. and Inceoğlu, M., 2019. Railroad buildings of Eskişehir: challenges and opportunites for industrial heritage. Heritage, 2, pp. 435-451. https://doi.org/10.3390/heritage2010030

Hecker, A., 2008. Le capital ferroviaire britanique, entre patrimoine et pragmaisme. Revue Geographie de l'Est, 48(1-2), pp. 1-20.https://doi.org/10.4000/rge.1241

Herman, G.V., Caciora, T., Ilies, D.C., Ilies, A., Deac, A., Sturza, A., Sonko, S.M., Suba, N.S. and Nistor, S., 2020. 3D modelling of the cultural heritage: between opportunity and necessity. J. Appl. Eng. Sci., 10(1), pp. 27-30. https://doi.org/10.2478/jaes-2020-0005

Herner, K. 2019. Using 3D scanning in the protection of industrial heritage - the example of Queen Luise Adit. In: IMEKO TC-4 International Conference on Metrology for Archaeology and Cultural Heritage Florence, Italy, pp. 444448.

Jo, Y.H. and Hong, S., 2019. Three-dimensional digital documentation of cultural heritage site based on the convergence of terrestrial laser scanning and unmanned aerial 
vehicle photogrammetry. Int. J. Geo-Inf., 8(53), pp. 1-14. https://doi.org/10.3390/ijgi8020053

López, G.A. and Cruz, D.C., 2021. Experiences of knowledge transfer on industrial heritage using games, storytelling, and new technologies: a history of enterprises. J. Comput. Cult. Herit., 14(2), pp. 1-26.https://doi.org/10.1145/3424951

Martín-Lerones, P.M, Olmedo, D., López-Vidal, A., GómezGarcía-Bermejo, J. and Zalama, E., 2021. BIM supported surveying and imaging combination for heritage conservation. Remote Sens., 13, 1584, pp. 2-11.doi.org/10.3390/rs13081584

Mănescu, M., Brişan, E., Bărbulescu, C., Adrian, D. and Bellu, R., 2003. Documentare privind enciclopedia gărilor din România, (Documentation regarding the encyclopedia of the Romanian railway stations), Centrul de Documentare pentru Construcţii, Arhitectură, Urbanism şi Amenajarea Teritoriului, Bucureşti,

Romania https://feisbuchestii.files.wordpress.com/2012/02/enciclopediagarilor-din-romania-full-text.pdf (view at 12 Aug. 2021).

Merciu, G.-L., 2015. Explorarea digitală a muzeului locomotivelor $\mathrm{cu}$ abur din Reşiţa prin intermediul aplicaţiei Story Map Journal (Digital exploration of the steam locomotive museum from Reșița through Story map Journal Application). Annals of the Professional Association of Romanian Geographers, 6(6), pp. 17-28.http://www.apgranale.com/434209359

Merciu, C., Merciu, G.-L., Cercleux, L. and Drăghici, C., 2014 Conversion of industrial heritage as vector for cultural regeneration. Procedia Social and Behavioral Sciences, 122, pp. 162-166.https://doi.org/10.1016/j.sbspro.2014.01.1320

Merciu, F.-C., 2020. Rolul patrimoniului urban în construirea identităţii culturale (The role of urban heritage in creating cultural identity). Annals of the Professional Association of Romanian Geographers, 11(11), pp. 17-28.http://www.apgranale.com/448500377

Messaoudi, S., Messaci, N. and Chennaoui, Y., 2021. Classifying heritage resources of territories. Case of Bejaia. Urban. Archit. Construct., 12(2), pp. 107-132.

Monego, M., Fabris, M., Menin, M. and Achilli, V., 2017. 3D survey applied to industrial archaeology by TLS methodology. In: International Archives of the Photogrammetry, Remote Sensing \& Spatial Information Sciences, Florence, Italy, Vol. XLII-5/W1, pp. 449-454. https://pdfs.semanticscholar.org/ae1f/754258f921f8b91c3a6041 f8daf443d23980.pdf?_ga=2.92595678.250045543.1630071916750791955.1605641566 (view at 17 Aug. 2021). doi.org/10.5194/isprs-archives-XLII-5-W1-449-2017.

Michniack, D., 2016. Role of railway transport in tourism: selected problems and examples in Slovakia. Quaestiones Geographicae, 35(4), pp. 107-120. https://doi.org/10.1515/quageo-2016-0039

Nae, M., Dumitrache, L., Suditu, B. and Matei, E., 2019. Housing activism initiatives and land-use conflicts: pathways for participatory planning and urban sustainable development in Bucharest city, Romania. Sustainability, 11, 6211, pp. 126.https://doi.org/10.3390/su11226211
Nistor, S., Suba, N.-S. and Simion, A., 2011. Monuments restoration using 2D mapping from 3D scanned models. Mathematical Modeling in Civil Engineering, 7(1-2), pp. 233240.

Nistor, S. and Buda, A.S., 2013. Large industrial scanning. $\operatorname{RevCAD}, 15$, pp. $175-180$

Opitz, R.S., Ryzewski, K., Cherry, J.F. and Moloney, B., 2015. Using Airborne LiDAR survey to explore historic-era arhaeological landscapes of Montserrat in the Eastern Carribbean. J. Field Archaeol., 40(5), pp. 523-541. https://doi.org/10.1179/2042458215Y.0000000016

Piras, M., Di Pietra, V. and Visintini, D., 2017. 3D modeling of industrial heritage building using COTSs system: test, limits and performances. In: The International Archives of the Photogrammetry, Remote Sensing and Spatial Information Sciences, Bonn, Germany, Vol. XLII-2/W6, pp. 281-288. https://www.int-arch-photogramm-remote-sens-spatial-infsci.net/XLII-2-W6/281/2017/isprs-archives-XLII-2-W6-2812017.pdf (view at 14 Aug 2021). doi.org/10.5194/isprsarchives-XLII-2-W6-281-2017

Popoviciu, G., 2012. Strategies for a collaborative ecodevelopment. J. Environ. Prot. Ecol., 13(2), pp. 720-729.

Rădulescu, V.M., Rădulescu, G.M.T., Naș, S., Rădulescu, A.T., Bondrea, M. and Rădulescu, C.M., 2021. Synthetic analysis of geoinformatics technologies for preservation of cultural heritage, methodological approach. J. Appl. Eng. Sci., 11(1), pp. 33-40.https://doi.org/10.2478/jaes-2021-0005

Di Ruocco, G., Sicignano, E., Fiore, P. and D'Andria, E., 2017. Sustainable reuse of disused railway. Procedia Engineering 180, pp. 1643-1652, International High-Performance Built Environment Conference - A Sustainable Built Environment Conference 2016 Series (SBE16).

Sun, Y., Montazeri, S., Wang, Y. and Zhu, X.X., 2020. Automatic registration of a single SAR image and GIS building footprints in a large-scale urban area. ISPRS J. Photogram. Remote Sens., $170, \quad$ pp. $1-14$ https://doi.org/10.1016/j.isprsjprs.2020.09.016

Tache, A.T., Sandu, I.C.A., Popescu, O.-C. and Petrișor, A.-I., 2019. UAV solutions for the protection and management of cultural heritage. Case study: Halmyris archaeological site. Int. J. Conser. Sci., 9(4), pp. 795-804.

Taloş, A.M., Lequeux-Dincă, A.-I., Preda, M., Surugiu, C., Mareci, A. and Vijulie, I., 2021. Silver tourism and recreational activities as possible factors to support active ageing and the resilience of the tourism sector. J. Settl. Spat. Plan., 8 sp. iss., pp. 29-48.DOI: 10.24193/JSSPSI.2021.8.04

Wu, T.-C., Lin, Y.-C. and Hsu, M.-F., 2015. A study of 3D modeling for conservation work of large-scale industrial heritage structures: using the South Chimney of Taiwan Tile Corporation's Takao Factory as a case study. J Asian Archit. Build. Eng., 14(1), pp. 153-158. https://doi.org/10.3130/jaabe.14.153

Xiao, W., Mill, J., Guidi, G., Rodríguez-Gonzálvez, Gonizzi Barsanti, S. and González-Aguilera, D., 2018. Geoinformatics for the conservation and promotion of cultural heritage in support of the UN sustainable development goals. ISPRS $J$. 
Photogramm. Remote Sens., 142, pp. 389-406. https://doi.org/10.1016/j.isprsjprs.2018.01.001

Xu, D., Ji, S., Liu, J. and Wei, S., 2021. Automatic 3D building reconstruction from the multi-view arial images with deep learning. ISPRS J. Photogramm. Remote Sens., 171, pp. 155170.https://doi.org/10.1016/j.isprsjprs.2020.11.011

Ministry of Culture, 2015, List of Historical Monuments, Argeş county, https://patrimoniu.gov.ro/images/lmi-2015/LMI-AG.pdf (view at 02 Feb. 2021). 